\title{
Robert Musil's Cultural Diagnostics in the Light of Nietzschean Immunology
}

\author{
Stijn De Cauwer
}

Published online: 5 January 2012

(C) The Author(s) 2012. This article is published with open access at Springerlink.com

\begin{abstract}
Nietzsche was one of the first to point out the importance of immunological processes that are at work in any society to maintain its coherence against threats. At the same time, Nietzsche was aware that these immunological processes can become too rigid, ultimately even dangerous and self-destructive. Roberto Esposito has shown that Nietzsche's work contains at the same time the seeds of such a problematic form of immunology and another way of thinking immunology that could avoid the dangerous consequences. Nietzsche knew that a society which rigidly bans out all threats will rob itself of the capacity for revitalizing itself. I will show that the Nietzschean writings on immunology are a crucial influence on Robert Musil. Due to the complexities with this aspect of Nietzsche's work, this influence is not immediately obvious. Exploring this influence will help to clarify certain aspects of Musil's work, such as the prevalence of pathological behavior in Der Mann ohne Eigenschaften. Moreover, it will make clear why Musil was very critical of Nietzsche's legacy, while at the same time claiming that his work is full of possibilities which nobody takes up. To find a way to foreclose the dangerous forms of immunological thinking, for which people found inspiration in Nietzsche's work, Musil takes up another way of thinking immunology that also comes out of Nietzsche's thought.
\end{abstract}

Keywords Musil · Nietzsche - Der Mann ohne Eigenschaften · Immunology · Health · Cultural critique

S. De Cauwer

Research School in Culture and History, Utrecht University, Utrecht, The Netherlands

S. De Cauwer $(\bowtie)$

Sint-Annastraat 9, 3000 Leuven, Belgium

e-mail: stijndc@yahoo.com 


\section{Introduction}

Nietzsche has been described as one of the first thinkers who diagnosed the ailments of his time in terms of the immunological mechanisms of a society (Sloterdijk 2009; Esposito 2008). Similar to biological organisms, any community develops mechanisms by which it wants to preventively ward off possible harm. As became painfully clear in the twentieth century, these mechanisms to maintain the health of a community can become extremely violent and ultimately self-destructive. Nietzsche not only wanted to describe the ailments society was afflicted by, but he also explored at length the problems with an overly rigid and static view of health or normality. In fact, he wrote that the greatest diseases have come out of the attempts to counter disease $(1971,52)$. Because Nietzsche did not shy away from the full complexity of regarding a society in terms of health and sickness, his analysis contains not just one, but multiple lines of thought, which makes a presentation of Nietzsche's explorations of immunology a difficult task. In a recent reading, Roberto Esposito has discerned two mutually exclusive theoretical approaches in Nietzsche's writings on immunization: one which anticipates, at least as a thought experiment, the most destructive forms of biopolitics of the twentieth century and a second one, running counter to the first approach, which allows for a way of thinking 'immunological health' in such a way that could preclude the self-destructive tendency of immunological reasoning. This accounts for the complex and confusing legacy of Nietzsche's philosophy. His work contained both the seeds of the most deadly views that would come to prevail in Germany as very important cues for how to overcome these destructive views.

In his diaries, Musil wrote that he had been an avid reader of Nietzsche all his life. He regarded Nietzsche's work as a park full of possibilities, but a park that nobody walks in $(1976,50)$. This is a remarkable statement given the huge influence of Nietzsche on the German intellectual life of the early twentieth century. Musil did not hesitate to express his frustration with Nietzsche's legacy, with the way his work was read and used to justify certain dangerous trends. Throughout Der Mann ohne Eigenschaften, we can find a critical discussion with this problematic legacy. Musil's entire body of work can be described as a complex and incisive diagnosis of the 'symptoms' of his times, as he called it in his essay Der deutsche Mensch als Symptom. Musil's work is filled with clinical jargon when trying to dissect the problems of modern society. By the time Musil started writing, the usage of clinical language or the claim that society had become mad had almost become a commonplace amongst German and Austrian writers. Generally, the madness of society was accredited to the collapse of the old value system. Society was supposed to be in decline, immoral or in a state of degeneration. Musil's diagnostics should not be confused with the prevailing literary usages of clinical or psychiatric metaphors. Musil, like Nietzsche, was of the opinion that there was a panic-driven overreaction to the confusion and anxiety concerning the rapid changes and accelerating complexity of modern life. It was the attempt to counter this anxiety by clutching to a rigid form of morality that caused a particular pathogenic condition in society, which was spreading like wildfire. By rigidly trying to counter the madness 
and chaos of modern existence, including its vertigo-inducing complexity, a pathogenic condition was perpetuated by those who wanted to overcome it.

Due to the difficulties with Nietzsche's use of clinical language, it is not immediately obvious that Nietzsche's immunological analyses left a huge, formative imprint on Musil's work. If we leave aside all simplifying accounts of Nietzsche's thought and fully open up the ambiguities surrounding his diagnosis of society's sickness, we can begin to unravel the impact of Nietzsche's clinical language, with all its irreducible tensions, on Musil's body of work. We can also understand why Musil regarded Nietzsche's work as a rare source of unexplored possibilities, while his work was at the same time the source of inspiration for certain trends which, to Musil's frustration, were running havoc in the intellectual life of the twenties and thirties.

\section{The Pathology of Normality: Robert Musil's Cultural Diagnostics}

In 1911, the essay Das Unanständige und Kranke in der Kunst by the young Robert Musil appeared in the journal Pan. The Berlin police had confiscated an earlier edition of Pan for publishing excerpts of Flaubert's travel diaries, which were deemed to be obscene. Musil's article was a response to the practice of banning art for allegedly being pathological or obscene. The law stated that artistic representations were allowed if they were justified by the artistic purpose. Musil rightly points out that the artistic purpose of a work of art is not immediately recognizable and it is certainly not up to courts and police attorneys to decide upon the artistic merits of art $(1978,8,979)$.

This article was one of the first in which Musil explored certain themes which would become the core of the critical analysis of his time and the driving force behind his future artistic production. This text contains the blueprint of the critical observations that Musil would continue to develop in an increasingly sophisticated manner. Though the essay was written as a response to one specific case, it reveals a more general problem, which is the tendency to react in a morally rigid manner to the overwhelming complexity of modern life. Modernity had changed society beyond recognition in only a few decades. Old ways of living and ordering society were becoming obsolete in a society which entered the modern age with a relentless speed. The opening chapters of Musil's Der Mann ohne Eigenschaften capture the general confusion of life in the modern metropolis. The immediate response to all this change and novelty was one of shock. The outrage and even riots that accompanied the expositions of new art or the premieres of new forms of music were almost customary. All this overwhelming novelty and innovation made it seem as if modern society had gone totally mad. The old moral guidelines and order had been overturned and society was now spinning out of control. Musil noticed that there was a widespread tendency to react to all these changes by calling for a return to the past, to restore the old moral values as the only way to navigate through the confusing times.

In Das Unanständige und Kranke in der Kunst, Musil strongly opposes the „Sakristeigeplapper von der Mission des Künstlers“ (979). He rejects the tendency 
to judge art according to rigid moral categories, which also counts for judging human behavior along similarly narrow lines. He defends the view ,daß man-in dieser Zeit, die sich mit Dekadence und Gesundheit so viel ängstigt-die Grenze zwischen seelischer Gesundheit und Krankheit, Moral und Unmoral viel zu grob geometrisch sucht, wie eine Linie, die zu bestimmen und zu respektieren sei (und jede Handlung muß entweder diesseits oder jenseits sein)...“ (981). For Musil, a black and white view on health, as if one can draw a straight line between health and sickness, is nothing more than the rhetoric of people with a conservative, moral agenda eager to condemn every form of challenge or renewal. It is not the purpose of a work of art to represent the prevailing morals of society. On the contrary, for Musil, the art work dissolves the prevailing categories and traces new affinities and connections: „Das Bedürfnis nach (künstlerischer) Darstellung empfinden, heißt... etwas darstellen: seine Beziehungen zu hundert andern Dingen darstellen; weil es objektiv nicht anders möglich ist, weil man nur so etwas begreifbar und fühlbar machen kann, ... wie ja auch wissenschaftliches Verständnis nur durch Vergleichen und Verknüpfen entsteht, wie menschliches Verstehen überhaupt entsteht. Und wenn auch diese hundert anderen Dinge wieder unanständig oder krank wären: die Beziehungen sind es nicht, das Auffinden von Beziehungen ist es niemals“ (979-980).

The artist must follow the traces and connections he or she is exploring, and not reject them beforehand because they are 'immoral'. Even more, something which could be called 'pathological' or 'obscene' in daily life is no longer so as soon it has become the material for artistic exploration. In this view, art must per definition move beyond the status quo or the prevailing moral norms, in search for new and better norms. It is in this light that we can understand Musil's statements on the role of art in relation to health. He writes that the artist is interested in ,die Erweiterung des Registers von innerlich noch Möglichem und darum ist Kunst auch nicht Rechtsklugheit, sondern-eine andere“ (981). When an artist considers something he or she should not immediately judge its value or non-value, but he or she is interested in the unexpected side that this phenomenon opens up. Art does not repeat the existing norms, it seeks new norms, as Musil writes in these rather militant words: „Sie ist erobernd, nicht pazifizierend." Such a view will inevitably be rejected by those defending the moral order. In the essay, Musil strongly rejects a conservative reflex: „...man soll nach vorwärts reformieren und nicht nach rückwärts; gesellschaftliche Krankheiten, Revolutionen sind durch konservierende Dummheit gehemmte Evolutionen" (983). This statement is very indicative of Musil's attitude to times of crisis. One should not react to a period of crisis with panic, or by hysterically clinging on to old values, but by calmly assessing the situation, including the possibilities for new orderings that the crisis offers. One needs the courage to realize that times of crisis need new models of assessment and behavior. It gives you the opportunity to readjust your models because the old ones were proven to be inadequate. But this can only lead to anxiety in conservative minds for which anything new is a threat or a monstrosity.

Musil does not deny that people can be sick or immoral, but this should not be decided on the basis of narrow black and white pre-existing categories. Musil writes that the boundaries must be drawn differently. What is 'immoral' depends not on a 
pre-decided category, but on the total picture. He ends the article by writing that morality could be defined as a common goal, deciding on which behavior is appropriate and which is not, but this behavior should be 'appropriate' to new challenges and situations. So morality should always be renewed and readjusted, rather than being based on immutable, rigid laws. Morality should look forward, not backward: „Man definiere als Moral irgend ein Gemeinsamkeitsziel, aber mit einem größeren Maß gestatteter Seitenpfade. Und stimme die Bewegung darauf zu auf starken Vorwärtswillen, um nicht bei jedem Grübelchen am Weg Gefahr zu leiden, hineinzuplumpsen. “ An overly rigid form of morality will fall over the first bump in the road.

By dissolving the habitual categories and tracing new connections, it moves beyond the inadequate patterns people are stuck in. If we define 'health' as the capacity to move beyond obstacles ${ }^{1}$ and to be able to create new norms, then we can understand why Musil claims that art is a form of knowledge which expands our knowledge of the healthy: „Und auch die Kunst sucht Wissen; sie stellt das Unanständige und Kranke durch seine Beziehungen zum Anständigen und Gesunden dar, das heißt nichts anderes als: sie erweitert ihr Wissen vom Anständigen und Gesunden“ (980). What Musil is saying here is that by taking up the 'pathological' in its search for new connections, it expands our capacity to move beyond obstacles, and thus it contributes to the healthy and the moral.

It is remarkable to what extent this brief early essay contains a complete rethinking of the relationship between art and morality, health and pathology. Musil's central observation is that an overly rigid, moral response to the complexity of modern life will actually cause a condition which could be called pathological, or at least, pathogenic, and which created the psychological preconditions for the political excesses of the twentieth century. Musil compared the times to a madhouse. In 1913, Musil visited a psychiatric hospital in Rome. The compulsive, emotionally draining jerks and spasms of the inmates left a lifelong impression. ${ }^{2}$ From his early writings, Musil combined his critique of a rigid moral reaction with the description of compulsive, frantic behavior. The rigid reaction to the complexity of modern life only increased the incomprehension and the feeling of unease, which lead to compulsive and inadequate acts. In this sense, Musil confirmed the Nietzschean claim that the worst forms of sickness came out of the struggle against sickness.

The theme of a morality that has become hollow and dysfunctional was already the topic of Musil's first literary success, Die Verwirrungen des Zöglings Törless. In this novel, he described the moral struggles of a young boy in the military

\footnotetext{
${ }^{1}$ In his influential work The Normal and the Pathological, Georges Canguilhem defined health as the capacity to move beyond obstacles and to create new norms: "What characterizes health is the possibility of transcending the norm, which defines the momentary normal, the possibility of tolerating infractions of the habitual norm and instituting new norms in new situations... Health is a margin of tolerance for the inconsistencies of the environment" (1989, 196-197).

2 This experience recurs in different texts of Musil. He first wrote it down in the notebook with the number seven. It also recurs in the early essay Politisches Bekenntnis eines jungen Mannes, in which Musil senses a connection between what he witnessed and the political state of society. Finally, this experience was taken up in the chapter Die Irren begrüssen Clarisse from Der Mann ohne Eigenschaften (1976, 278-281, 1978, 8, 1014, 3, 977).
} 
academy, a portrait of the elite boarding school that Musil attended and where children of wealthy Austrian families were prepared for a career as army officer. ${ }^{3}$ Considered to be one of the prestigious educational institutions that was supposed to instill an unshakable loyalty, unquestionable moral values and a sense of duty in the future members of the Austrian elite, the description that Musil gave of the homoerotic, sadistic and proto-fascist games the pupils were involved in, must have been a great shock. When Törless gets exposed to the severe and soulless moral codes of the school, but at the same time gets involved in the dark sexual and violent outbursts that go on at night, unquestionably accepting his moral duty is something that turns out to be a much more difficult thing to do than he expected. There seems to be no natural or rational form of motivation to do so, other than avoiding a constant crisis of his conscience. The novel relentlessly exposed the dangers of presuming a moral order, especially when it had become inadequate for the complexity of modern existence. The reason that the novel was so controversial was because it exposed the monstrosities an overly complacent view of normality and morality can engender. It was a superb dissection of what Canguilhem called "the disease of normal man" (1989, 286): a rigid conception of normality will evoke the worst forms of pathology.

As Törless 'moral and sexual crisis inevitably escalates, Musil provides the reader a glimpse of Törless' future as an adult, who has fully repressed the confusions of his adolescence, becoming a man ,welchen die Beachtung der Gesetze und wohl auch teilweise der öffentlichen Moral eine Beruhigung gewährt, weil sie dadurch enthoben sind, über etwas Grobes, von dem feineren seelischen Geschehen Weitabliegendes nachdenken zu müssen..." $(1978,6,111)$. He finds solace in the customs and habits of social conventions. In his diaries, Musil uses the term morality of duty (Pflichtmoral) $(1976,434)$. We hear more than a small echo here of what Nietzsche in Morgenröthe has called the morality of custom (Sittlichkeit der Sitte): „Sittlichkeit is nichts Anders (also namentlich nicht mehr!), als Gehorsam gegen Sitten..." (1971, 17-18).

In the unfinished essay Der Deutsche Mensch als Symptom, from 1921, Musil worked out this dynamic as the general condition of people. In his view, people cannot cope with the contingency and frailty of their existence: „Der persönliche Tod, die Winzigkeit des Erdkügelchens im Kosmos, das Geheimnis der Persönlichkeit, die Frage des Fortlebens, Sinn und Sinnlosigkeit des Daseins, das sind Fragen, die der Einzelne in den meisten Fällen als ohnedies nicht beantwortbar zeit seines Lebens abweist, und die er dennoch wie die Wände eines Raums sein ganzes Leben umschließen fühlt. Ich glaube auch, daß wenig Menschen ganz unberührt davon bleiben, daß es statt ihres Lebens auch ein anderes gäbe..." (1978, 8, 1357). To avoid the constant existential angst over our lives or the intense doubt that will arise when one realizes the contingency of what we find the most important, people adopt pre-existing moral models. Morality, or as Musil liked to call it, 'petrified morality', serves as a firm guideline for people to feel like they belong to a

\footnotetext{
3 As a child Robert Musil was sent to the military boarding schools of Eisenstadt and MährischWeisskirchen. Rilke, who shortly went to the same school at Mährisch-Weisskirchen, had to be removed by his parents after less than a year, remaining traumatized by his stay there for the rest of his life.
} 
meaningful, ordered society, in which they have a specific role and place: „Sobald dagegen eine Seele Moral hat oder Religion, Philosophie, vertiefte bürgerliche Bildung und Ideale auf den Gebieten der Pflicht und des Schönen, ist ihr ein System von Vorschriften, Bedingungen und Durchführungsbestimmungen geschenkt, das sie auszufüllen hat, ehe sie daran denken darf, eine beachtenswerte Seele zu sein... Es bleiben dann im Grunde nur noch logische Fragen der Auslegung übrig, von der Art, ob eine Handlung unter dieses oder jenes Gebot fällt..." (1, 186). After decades, people grow to be accustomed to these moral guidelines, which Musil calls Kunstgriffen, artificial systems, and regard these interlocking value systems to be the natural state of things. Musil wrote that such a presumed, natural moral order makes all 'moral imagination' wither away. This was particularly problematic in the popular nationalist or racial rhetoric. He wrote: „Wenn im Guten und Bösen für alles nicht der Einzelne verantwortlich gemacht wird, sondern die Rasse, wirkt das genau so, wie wenn man sich immer auf einen anderen ausredet; die Folge ist nicht nur, daß Wahrhaftigkeit und intellektuelle Feinheit abstumpfen, sondern eine Entartung aller Keimzellen der Moral. Wo die Tugend durch Prädestination zum Nationaleigentum erklärt wird, ist der Weinberg des Herrn expropriiert, und niemand braucht fortab in ihm zu arbeiten. Es wird dem Einzelnen vorgeschmeichelt, er besitze alles Wünschenswerte, so er sich nur auf die Tugenden seiner Rasse besinne: offenbar ein moralisches Schlaraffenland, unser glückliches Deutschland, wo die gebratenen Tugenden ins Maul fliegen!“ $(8,1065)$

Musil called state, nation and race the 'mystical fetishes' of his time. The fixation on these idealized fetishes made the moral (and intellectual) creativity wither away. All agency was entirely relayed to an abstract ideological entity which was valued for itself. Musil saw the function of these fetishized notions as a „, Überwälzungsidealismus', der die Würde, die der Mensch für sein persönliches Leben nicht zu gewinnen vermag, auf dessen Hintergrund überträgt, auf die Rasse, auf seinen Kaiser, auf einen Verein, auf die Erhabenheit des Sittengesetzes oder sonst eine Tapete" (1241). Instead, the task was to find an ethics which does not romantically call for a return to the past or is fixated on certain fetishes, but which has the flexibility and creativity to cope with the change, novelty and complexity of modern life. Rather than presuming a static order, an approach is needed which allows itself to be transformed by the new demands of rapidly changing contexts. For Musil, the present was not simply a matter of a failed system, an order falling apart that needs to be restored, but an opportunity to develop new orderings. The present has to be treated as a new question, demanding new forms of thought: „... so kennzeichnet sich unsre Zeit auch in diesem Fall durch einen ungeheuren geistigen Romantizismus, der aus der Gegenwart in alle Vergangenheiten flüchtet, um dort die blaue Blume der seelischen einer verlorenen Sicherheit zu finden. Aber es wird allgemein darin die Zersetzung eines früheren Zustands gesehen, der fester gewesen sein soll, der Verlust von Dogmen und Richtlinien, die Auflösung von Bindungen, mit einem Wort ein Zerfall, und gerade daß diese mutlose Annahme nicht notwendig ist, wünsche ich zu zeigen. Der heutige Zustand des europäischen Geistes ist meiner Ansicht nach kein Verfall, sondern ein noch nicht vollzogener Übergang, keine Überreife, sondern Unreife“ (8, 1367). Only through an openness for what seems overwhelming, insane and out of control can one develop an ethics that could lead 
the way out of the condition that paved the way for unimaginable destruction and bloodshed. It is for this reason that Musil could controversially claim that Germany's collapse in the First World War was not caused by the immoral people but by the moral ones $(1996,586)$.

By looking at the complexities of Nietzsche's writings on disease and possible forms of immunization, we can understand in what way Der Mann ohne Eigenschaften will try to cope with the symptoms of the time.

\section{The Double Legacy of Nietzschean Immunology}

Throughout his life, Nietzsche attempted to pinpoint a certain sickness which profoundly affected the lives of modern human beings. In Zur Genealogie der Moral, Nietzsche diagnoses a Christian-Platonic obsession with another world beyond this one as the disease his times is suffering from, draining the strength and joy of life out of the people. The disease Nietzsche describes is a problematic response to the hardships and challenges of life. What makes people afflicted with this disease is not the fact that they are faced with difficulties and obstacles, but the problematic ways of reacting to these difficulties. Instead of facing this life, with all its suffering, changeability and contingency, people invented a Hinterwelt wherein they place all their hope. They invent a metaphysical other-world, where perfect order and justice reign, as opposed to this world.

How then did Nietzsche want to counter this illness? If the belief in a Hinterwelt is the disease of his times, then how did he conceive of 'health' or a possible cure? Nietzsche's answer to this was not to place himself squarely on the side of 'health'. Just like everybody else, Nietzsche was suffering from the same metaphysical sickness. On several occasions Nietzsche evoked the figure of he who is curing, from Zarathustra to Nietzsche himself in Ecce Homo. ${ }^{4}$ The cure, a process which will never come to a complete end, will have to be an acceptance of this world as it is; this means, as a world in constant change, in which there is no inherent order or morality, in which suffering and hardships are common, a world without telos, meaning or goal. How could people be made to face this world as it is, without seeking an escape in an other-worldly realm? This could only be achieved by increasing the sickness. The suffering will have to be increased, so that people will have to make a choice: do I accept this world as it is or not? Only an acceleration of the suffering could lead, for Nietzsche, to an attitude of joyful acceptance, of play and experimentation with this world. The disease is a moral shock, it disturbs our habits and places us for a drastic choice. While illness could chase people into otherworldly beliefs, it could also operate as a corrosive, eroding the metaphysical constructions of a hinter-welt and force people to accept their present conditions.

In a recent work, Alenka Zupancic has clarified certain important features of this sickness, the belief in a Hinterwelt and the accompanying ascetic ideal. She points

\footnotetext{
${ }^{4}$ Nietzsche signed a letter to Wagner with der Basler Genesende (KSB, 4,157-4,158). He too is ill, but he wants to overcome this situation. This process can never come to a full resolution. In a commentary on this passage, Groot writes that one never fully possesses health, only the will to become healthy (2003, 72).
} 
out that what Nietzsche called the 'ascetic ideal' was not a form of repression but, on the contrary, the instigation of feelings. The instigation of strong feelings had to outdo the feeling of unease about the times. Because of the importance of this insight, I will quote Zupancic at length: "It might seem that the notion of the ascetic ideal, as Nietzsche's analysis and criticism of it, somehow belongs to the past, and has no particular relevance to our largely hedonistic 'postmodern' condition'. Yet, this assumption could not be more erroneous. The hedonism of postmodern society, far from representing a step out of the framework of what Nietzsche calls the ascetic ideal, is deeply rooted in this framework. In order to see this, we must first understand that, for Nietzsche, the ascetism involved in the ascetic ideal does not simply involve a renouncement of enjoyment; it involves, above all, a specific mode or articulation of enjoyment. ... If, according to Nietzsche, all great religions are an answer to man's feelings of displeasure and pain, they never treat the cause of this displeasure. Instead, they soothe the sensation of displeasure-they soothe it by providing an even stronger sensation. They literally 'outscream' the displeasure (and the 'depression' - this is Nietzsche's term-linked to it) with an even sharper and more acute feeling, on account of which we no longer feel the previous displeasure. The religious (and especially Christian) cure for 'depressive discomfort' comes not in the form of an analgesic or a tranquilizer, but, rather, in the form of an 'irritating drug' or 'excitation-raiser,' a stimulant" (2003, 47). Similarly, Musil never ceased to point out the dangerous emo-politics which dominated the first half of the twentieth century. People were seeking new ideas, slogans, prophets, enigmatic leaders or mass movements which could incite in them a feeling of excitement and of belonging to a meaningful whole. We know that the Nazis eagerly exploited the arousal of the masses. In times of great unease or depression, there is an increasing popularity of movements that are openly anti-intellectual and play on gut sentiments and the longing for a community to be proud of. It is no coincidence that recent years have seen the rise of such movements once again.

Roberto Esposito has called Nietzsche the extraordinary seismograph of later developments in the complex relations between life, health and society. While processes of immunization in principle have the aim to keep a society healthy and to protect it from forces which threaten to dissolve or harm society, they have the dangerous tendency to go too far. Processes of immunization can become too strict and rigid and ultimately even turn against society itself, like a form of autoimmunity disease. What was supposed to preserve life can become a dangerous form of 'thanatopolitics', a deadly killing machinery. The paradigmatic example of this is of course the Nazi regime, but the Nazi policies were an excessive escalation of dynamics which had been developing for a long time. Originally targeting specific groups such as the Jews as a 'contaminating' threat which had to be 'removed' to preserve the health of the social body, Hitler ended up by condemning the entire German people to death in his final hours in the bunker. ${ }^{5}$

In the work of Nietzsche, Esposito finds a double tendency: one which unambiguously anticipates the destructive side of the immunization processes, but also a second one, which runs counter to the first tendency and which suggests a

\footnotetext{
5 The entire chapter 4 of Esposito's book is an analysis of the Nazi thanatopolitics (2008, 110-145).
} 
way to move beyond the destructive extremes of these immunization processes. In these two lines of thinking, which appear in Nietzsche's writings alongside each other, there is a different conception of the relation between disease and society. In the first line of thought, Nietzsche describes forces which are purely and unambiguously contaminating, posing a threat to the health of a person or society. These forces cause a degeneration that is irreversible. Thus, the only way to relate to these ill-making forces is to forcefully remove them. Nietzsche's oeuvre is filled with statements about protecting oneself against the weak and debilitating forces. To just give one example: „Moral für Ärzte.-Der Kranke ist ein Parasit der Gesellschaft. ... Eine neue Verantwortlichkeit schaffen, die des Arztes, für alle Fälle, wo das höchste Interesse des Lebens, des aufsteigenden Lebens, das rücksichtsloseste Nieder- und Beiseite-Drängen des entartenden Lebens verlangtzum Beispiel für das Recht auf Zeugung, für das Recht, geboren zu werden, für das Recht, zu leben“ $(1969,128)$. This side of Nietzsche is the one which anticipated, at least theoretically, the bloodiest eugenics programs conducted in the name of the 'health' of society.

But Esposito also finds another aspect in Nietzsche's work which allows for redefining health and disease in relation to society and which provides the blueprint for a way of thinking that could dismantle the destructive excesses of the immunization logic of a society. In this second mode, certain forces are no longer seen as an unambiguous and irreversible threat to the health of society. On the contrary, Nietzsche is aware that an overly rigid exclusion of all contamination, threats or risks will destroy the vitality of a society. In Menschliches, Allzumenschliches, Nietzsche expresses this line of thinking in relation to the state: „Der Staat ist eine kluge Veranstaltung zum Schutz der Individuen gegen einander: übertriebt man seine Veredelung, so wird zuletzt das Individuum durch ihn geschwächt, ja aufgelöst,- -also der ursprüngliche Zweck des Staates am gründlichsten vereitelt" $(1967,201)$. As Esposito writes: "The thesis he advances is that such a logic cures illness in a self-contradictory form because it produces a greater illness than the one it wanted to prevent. ... Impeding the possible dissolution of the organism, they also stop its growth, condemning it to stasis and impoverishment" $(2008,91)$. It is in this sense that Nietzsche could say that the worst forms of disease come from the struggle against disease. Paradoxically, but also attesting to the richness of Nietzsche's work, this second line of thinking could be read as a warning against the destructive attempts at immunization, which are present in Nietzsche's writings as well.

Blocking out any threat or danger robs a society of its capacity for growth and renewal. Health is no longer opposed to disease, but is a state achieved by overcoming disease. In the words of Esposito: "Health is not separate from the mortal risk that runs through it, pushing it beyond itself, continuously updating its norms, overthrowing and re-creating rules for life... if health is no longer separable from sickness; if sickness is a part of health - then it will no longer be possible to separate the individual and social body according to insurmountable lines of prophylaxis and hierarchy" (104). Esposito remarks that Nietzsche still uses the language of immunization or vaccination, but there is a crucial difference with the destructive form of immunization. In the latter case, the aim is the preservation of a 
certain state of affairs, while in the former the aim is the transformation of a given state: "But the logic that underpins it is not directed to preserving identity or to simple survival, but rather to innovation and alteration. ... From this perspective, the negative not only is in turn detained, repressed, or rejected, but it is affirmed as such: as what forms an essential part of life, even if, indeed precisely because, it continually endangers it, pushing it to a problematic fault line..." (106). For Nietzsche, only a person who is not interested in preserving one's identity but who is open to radical forms of exteriority, forcing him or her to transform, will be capable of true health: "His being resides beyond this or beyond that side of the identity with himself. And indeed, he is not even a being as such, but a becoming that carries together within itself the traces of a different past and the prefiguration of a new future. At the center of this conceptual passage lies the theme of metamorphosis" (107).

The two mutually exclusive lines of thought in Nietzsche's work account for the fact that the most diverse people have claimed to be influenced by Nietzsche. It also clarifies why Musil can claim that Nietzsche's work is like a park full of unexplored possibilities, and yet, at the same time the Nietzschean impact on German culture was immense. Many of the intellectuals Musil found objectionable, such as Oswald Spengler, based their ideas on Nietzsche as well. Esposito's reading of a Nietzschean form of immunology, of a new way of thinking the relation between health and disease, normality and pathology, society and its 'exteriority', allows us to clarify the profound Nietzschean influence on Musil's cultural diagnostics and at the same time Musil's objections to the legacy of Nietzsche's philosophy.

\section{Nietzschean Immunology in Der Mann Ohne Eigenschaften}

Reading Der Mann ohne Eigenschaften is like entering a world which seems to have gone totally mad. Jonsson begins his review of Karl Corino's biography of Musil in the following way: "To read Robert Musil is to sense an approaching catastrophe. His narratives spiral downward from the daylight of bourgeois conventions into the night of madness, the negativity of disorder, criminality and war" (2004, 131). Pathological behavior in Der Mann ohne Eigenschaften is so abundant in Musil's work that it became a recurrent source of criticism. It caused critics to accuse him of the typical obsession with morbidity, reflecting the decadence of wealthy and bored modern city dwellers. Already in 1956, Georg Lukács accused writers such as Musil of having an obsession with the pathological as a goal in itself. In Lukács' reading, the obsession with psychopathology of modernist writers was an inadequate reaction to life under capitalism, which he finds exemplified by Der Mann ohne Eigenschaften: „Es ist unzweifelhaft eine positive Eigenschaft Robert Musils, dass er über die Bedingungen und Folgen seiner schöpferischen Tätigkeit eine gewisse Bewusstheit besitzt. Er sagt z. B. über seinen Helden Ulrich einmal: ,Man hat nur die Wahl, diese niederträchtige Zeit mitzumachen (mit den Wölfen zu heulen) oder Neurotiker zu werden.' Damit wird das Problem der Rolle der Pathologie in der avant-gardeistischen Literatur unserer Tage ernsthafter als im allgemeinen aufgegriffen“ $(1958,27)$. 
Does Musil describe a world which has hopelessly gone astray, including the protagonist, who can only succumb to the escalating chaos and incapacity to change this? Does Ulrich display the same, or even worse, outlandish behavior as the other characters of the novel, or is he in some way distinctly different from the others? Does Ulrich, as Lukàcs claims, flee from the complexity of the present into a private world of eccentricity? For a long time, these were questions preoccupying Musil scholarship. However, the function of pathological behavior in Der Mann ohne Eigenschaften can be understood in the light of the subtleties and ambiguities of Nietzsche's immunology.

We can find the same double function of pathology in Musil's writings as the role of sickness in Nietzsche. For Musil, the pathology of the times is an inadequate response to the challenges and changes of modern life. Incapable of facing the complexities, novelty and problems of the present, people flee into a moral Hinterwelt. Confused by the present, people cling to a construction of moral order, often associated with the 'mystical fetishes' of state, nation and race. Moral order is presumed to be there and associated with national or group traits. As Musil wrote, morality is thus expropriated as a form of predestination and nobody needs to work on it anymore. In Der Mann ohne Eigenschaften, the pathology of the times, in all its facets, is not simply described or denounced. Instead, it is accelerated, pushed to extremes, so the inadequacy of the moral constructions becomes obvious. The pathological behavior exposes the inadequacy of the prevailing frameworks to make sense of the present and that other ways of approaching it are possible and necessary. Increasing the pathological symptoms corrodes the petrified morality and the belief in a natural order. This is not just some kind of a Verelendigung, an escalating of destructive forces for the sake of itself. On the contrary, it opens up the capacity to face the present in all its complexity, to conceive of new ways of responding to it and to experiment with the possibilities that modern life contains. The increased Möglichkeitssin, which Musil advocates, can only take place if people no longer see a certain formation of reality as the one and only way things could be. This idea can already be found in Nietzsche, who wrote in Vom Nutzen und Nachtheil der Historie für das Leben : „Meint man doch, es gäbe gar keine andre Möglichkeit als eben unsere jetzige höchst leidige Wirklichkeit“ (1972, 322).

Musil too was aware that an overly rigid defense or inoculation against threats would make a society even more ill, even dangerously so. In Der Mann ohne Eigenschaften we can find several characters who defend the view that we should unquestionably and firmly adhere to the prevailing moral system because it provides the best and most certain guideline for life. Question this moral guidance and you will quickly slide towards confusion and insanity. Early in the novel, it is Ulrich's father who most clearly expresses this view of morality as a necessity for existing. He lives by the principle: ,Wenn man gut durch geöffnete Türen kommen will, muß man die Tatsache achten, daß sie einen festen Rahmen haben“ (1978, 1, 16). Or in the ironic, mocking words of Ulrich: „Sein Vater würde es ungefähr so ausgedrückt haben: Wen man tun ließe, was er wolle, der würde sich bald vor Verwirrung den Kopf einrennen. ... Diese Altvordernweisheit kam ihm als ein außerordentlich neuer Gedanke vor. Es muß der Mensch in seinen Möglichkeiten, Plänen und Gefühlen zuerst durch Vorurteile, Überlieferungen, Schwierigkeiten und Beschränkungen 
jeder Art eingeengt werden wie ein Narr in seiner Zwangsjacke, und erst dann hat, was er hervorzubringen vermag, vielleicht Wert, Gewachsenheit und Bestand; - es ist in der Tat kaum abzusehen, was dieser Gedanke bedeutet!“ (20-21)

In the view of Musil's father, accepting the traditional moral code is as necessary as solid door frames and without it, the world would slide into random chaos and excess. Even more, it is a necessity for people to maintain a grip on themselves. Let that grip go, and you end up on a slippery slope towards insanity, crime and confusion. Morality thus understood entails the avoidance of too many possibilities or the neurotic anxiety of having too much freedom and choices, as Musil described in Der deutsche Mensch als Symptom.

Musil was well aware that many of the opinions he found objectionable or even dangerous were justified by referring to Nietzsche. Throughout Der Mann ohne Eigenschaften, there is an ongoing struggle against popular readings of Nietzsche's work. As Esposito has shown, Nietzsche's writings contain the germs of ways of thinking which would become dangerously dominant: an uptight form of immunological rationale that wants to drastically defend the 'health' of society against all forms of presumed contamination (this could range from groups of people, modern art or rationality). Such rigidity in the face of novelty and challenge was critiqued at length by Musil. To find ways to overcome a problematic legacy of Nietzsche's philosophy, Musil takes the cue from Nietzsche as well.

As opposed to the preservation of a given status quo, by hysterically rejecting all threats and challenges, these challenges should be welcomed as an opportunity to transform and to achieve a new and better condition. This is a process which can never reach an ultimate equilibrium or final end, but always has to continue. Of course, Musil's 'man without qualities' is precisely such a person who does not try to cling on to a certain identity or state, but who is radically open to contingency, challenges and self-transformation. ${ }^{6}$

Ulrich is affected by the same effects of modern city life as everybody else, but he chooses to relate differently to them. Let us not forget that Musil preferred to call the phenomena he was describing symptoms. It makes no sense to denounce a symptom or simply describe it as inadequate. A symptom will require a lengthy and thorough working through to free the problems and affects that the symptom tries to cope with from petrified, compulsive repetitions. Like Nietzsche, Ulrich adopts a different relation to his condition. It is no longer considered to be purely a negative state, which one should flee into as if an idealized realm or a romanticized past, but an opportunity to develop a new ethos, which implies a total transformation of human life. As opposed to what Musil called the Überwälzungsidealismus, this transformation will not come from fetishized ideals but, on the contrary, from rendering such fetishes inoperative so people can once again experiment with other ways of living. In Morgenröthe, Nietzsche describes what happens when people are finally freed from teleological thinking. The fact that people, in order to acquire salvation in the afterlife, had to gather all the proper knowledge during a very brief

\footnotetext{
6 In Les maladies de l' home normal, Guillaume Le Blanc ends his exploration of the problems with the notion 'normality', inspired by Canguilhem, with a plea for 'a new man without qualities' (189-190). Le Blanc sees in Der Mann ohne Eigenschaften a model for overcoming the dangers of a rigid conception of normality.
} 
life span, led to a sense of urgency and gave knowledge a frightful weight. But when people free themselves from this urgency, they regain the benefits of error: „Wir haben den guten Muth zum Irren; Versuchen, Vorläufig-nehmen wieder erobert... und gerade deshalb können Individuen und Geschlechter jetzt Aufgaben von einer Großartigkeit ins Auge fassen, welche früheren Zeiten als Wahnsinn und Spiel mit Himmel und Hölle erschienen sein würden. Wir dürfen mit uns selber experimentieren! Ja die Menschheit darf es mit sich!“ (1971, 298)

The rupture of the eschatological frees up the possibility of experimentation and the capacity to readjust one's positions, values or opinions. It allows for error in the positive sense that the sciences give it, as a necessary component of refining and readjusting one's hypotheses to new facts. Musil developed an inductive, experimental ethos as a way to cope with the challenges of modernity; not a strict set of moral rules, but an experimental approach like in the modern sciences, which threats phenomena as hypotheses which can be tested experimentally. The last public address that Musil gave in Vienna in 1936, Uber die Dummheit, described a compulsive and destructive form of stupidity, which had become institutional. At the end of the speech, Musil suggests the following imperative to counter this situation: „Handle, so gut du kannst und so schlecht du mußt, und bleibe dir dabei der Fehlergrenzen deines Handelns bewußt! “7 $(1978,8,48)$ In Musil’s experimental ethos we can hear an echo of Nietzsche's “courage for error, for experimentation, for accepting provisionally". Musil wanted to find a way to apply the approach of the modern sciences to our daily lives, but the cue for such an ethos of provisional and hypothetical thinking comes from Nietzsche. In his diaries, he commented on a passage from Nietzsche's Menschliches, Allzumenschliches, where Nietzsche calls people who desperately cling to their first opinions unscientific: „Jeder der in dem Glauben hängen bleibt, in dessen Netz er sich zuerst verfing, ist verdächtig. Er begreift nicht, daß es andere Meinungen geben müsse. Diese Geister nennt N[ietzsche] ,unwissenschaftlich'. [...] Sobald sie für eine Sache [...] die erste Hypothese finden, so legen sie sich darauf fest. Eine Meinung haben, heißt bei ihnen schon: dafür sich fanatisieren u sie als Überzeugung fürderhin sich ans Herz legen“ (1976, 477). In such a view, challenges and obstacles allow us to improve our models and approach. They are a prerequisite for any learning process.

In Der Mann ohne Eigenschaften, the character Clarisse endorses a one-sided reading of Nietzsche, with an overemphasis on the Dionysian. She is all impulse without an awareness of an error-margin. She misses the proper attitude to readjust one's provisional approach in the light of obstacles and changing conditions. Clarisse is 'unscientific' in the sense Nietzsche gave it. It was the critique of Lukács that a writer like Musil supposedly held the opinion that in order to flee the madness of the capitalist world one had to become mad oneself. According to the critique of Lukács, Musil can only answer to the chaos of modern life with a flight into the pathological. This view is voiced by Clarisse during a visit to Moosbrugger in the psychiatric institution: „Man muss den Mut dazu haben, wenn die Weit wieder recht werden soll! Es muss von Zeit zu Zeit Menschen geben, die nicht mitlügen!“‘ (1978,

\footnotetext{
7 "Act as well as you can and as badly as you must, but in doing so remain aware of the margin of error of your actions" $(1990,286)$.
} 
4, 1369) It is Clarisse who does such a thing, trying to counter the chaos of the times with a flight into the irrational and madness, but it was Musil's aim to move beyond such an inadequate response. In Der Mann ohne Eigenschaften we can find an elaborate attempt to overcome the symptomatic, destructive behavior that overly uptight immunological processes will engender. For this, it will be necessary to have an approach that does not automatically rejects all threats and challenges, but that allows them to a certain extent so new and more adequate approaches can be developed. This does not mean sliding towards total irrational madness, chaos and destruction like Clarisse. The aim is to find a proper immunological relation to the continuous change, novelty and threats that always challenge our equilibrium. For this, Nietzsche provided important insights which Musil took up to develop in his masterpiece.

Open Access This article is distributed under the terms of the Creative Commons Attribution Noncommercial License which permits any noncommercial use, distribution, and reproduction in any medium, provided the original author(s) and source are credited.

\section{References}

Canguilhem, G. (1989). The normal and the pathological. New York: Zone Books.

Esposito, R. (2008). Bios; biopolitics and philosophy. London: University of Minnesota Press.

Groot, G. (2003). Vier ongemakkelijke filosofen; Nietzsche, Cioran, Bataille, Derrida. Amsterdam: Uitgeverij SUN.

Jonsson, S. (2004). A citizen of Kakania. New Left Review, 27(May, June), 131-141.

Le Blanc, G. (2007). Les maladies de l'homme normal. Paris: J. Vrin.

Lukács, G. (1958). Wider den missverstandenen Realismus. Hamburg: Claassen.

Musil, R. (1976). In A. Frisé (Ed.), Tagebücher. Reinbek bei Hamburg: Rowohlt.

Musil, R. (1978). In A. Frisé (Ed.), Gesammelte Werke in neun Bänden. Reinbek bei Hamburg: Rowohlt.

Nietzsche, F. (1967). Menschliches, Allzumenschliches. In G. Colli \& M. Montinari (Eds.), Werke. Kritische Gesamtausgabe (Band IV2, pp. 259-430). Berlin: Walter de Gruyter \& Co.

Nietzsche, F. (1969). Götzen-Dämmerung. In G. Colli \& M. Montinari (Eds.), Werke. Kritische Gesamtausgabe (Band VI3 pp. 49-154). Berlin: Walter de Gruyter \& Co.

Nietzsche, F. (1971). Morgenröthe. In G. Colli \& M. Montinari (Eds.), Werke. Kritische Gesamtausgabe (Band V1, pp. 1-335). Berlin: Walter de Gruyter \& Co.

Nietzsche, F. (1972). Unzeitgemässe Betrachtungen. In G. Colli \& M. Montinari (Eds.), Werke. Kritische Gesamtausgabe (Band III1, pp. 153-423). Berlin: Walter de Gruyter \& Co.

Sloterdijk, P. (2009). Du musst dein Leben ändern; über Anthropotechnik. Frankfurt am Main: Suhrkamp. Zupancic, A. (2003). The shortest shadow; Nietzsche's philosophy of the two. Cambridge, MA: The MIT Press. 